\title{
China's Opening-up Strategy in the Milieu of Belt and Road Initiative
} (BRI)

\author{
Gao Wei ${ }^{1,2}$, Wang Lin $^{3}$, Yan Jingdong ${ }^{1} \&$ Wu Yanxiong ${ }^{4}$ \\ ${ }^{1}$ School of Management, Wuhan University of Technology, Wuhan, China \\ ${ }^{2}$ International Exchange College, Hankou University, Wuhan, China \\ ${ }^{3}$ Admission Unit, Hankou University, Wuhan, China \\ ${ }^{4}$ Jiyang College of Zhejiang A\&F University, Zhuji, China \\ Correspondence: Yan Jingdong, School of Management, Wuhan University of Technology, Wuhan 430000, Hubei, \\ China. E-mail: yjdong02@163.com; Wu Yanxiong, Jiyang College of Zhejiang A\&F University, Zhuji 311800, \\ Zhejiang, China. E-mail: 13601213097@163.com
}

Received: November 27, 2020

Accepted: January 28, 2021

Online Published: March 3, 2021

doi:10.5539/jpl.v14n3p6

URL: https://doi.org/10.5539/jpl.v14n3p6

\begin{abstract}
The Chinese economy is changing its development model from invest/export-led growth to consumption/growth driven by domestic demand. In the recent domestic-oriented growth phases of China's opening-up policy, what role is expected to play? Not only is this a way to acquire foreign exchange and technology, but it is also an economic powerhouse for China that strengthens its position in global governance. General Secretary Xi Jinping's proposed the "Belt and Road" initiative in 2013, which is considered an excellent strategy for China's new round of opening-up policy. This research paper aims to bring the BRI inside China's open-up policy and focuses on its increasingly important role in controlling major global economic regimes. The study also shows the importance of establishing systems of mutual aid/funding for the countries participating in BRI. The first section of the paper looks at China's reactions to major economic regimes. Section two reflects the design and the implementation of the opening-up strategy for China from the BRI perspective. Section three of the research addresses Chinese development aid/funding in the BRI and its relation to foreign regimes. The fourth part addresses the BRI's trade relationship with the participating countries, using the gravity model from a global commercial perspective. The study concluded that cross-border financial cooperation between government and business participants is vital for the development of a successful investment and funding system for the BRI. It reiterated the importance of using foreign and regional financial centers to develop a regional structure within the BRI's investment and financing system.
\end{abstract}

Keywords: opening-up, belt and road initiative, China

\section{Introduction}

China's open-up policy for the rest of the world, introduced in the 1970s, led to a perception of an economic miracle through the rapid expansion of exports and the captivation of significant foreign direct investment (FDI). During this time, foreign enterprises made an essential contribution to the Chinese economy. Micheal J. Enright's economic impact analysis, along with local suppliers and consumer spending by their domestic workers, accounted for 33 percent of GDP and 27 percent of jobs over the last five years on average between 2009-2013 (Enright, M.J. 2016).

Thirty years later, however, China faces a growing "double surplus" on the current and capital accounts. Adverse effects have gradually emerged because of excessive liquidity, intensive investment/ production, increasing prices for assets (salaries, resource prices, land prices, and exchange rates) and foreign trade uncertainty (Ohashi, H. 2015). Therefore, China is looking to change its development model from growth driven by an investment/exportled growth driven by domestic demand/consumption (Ibid: 86). China is striving to jointly acquire foreign exchange and technology while adopting an export-oriented model of growth. As the development model continues to change, China's opening-up strategy has entered a new phase, and efforts are underway to reform the economic system and existing industries by shifting export factors to domestic provinces and foreign countries. Under the current settings, China is gradually extending its pledges to several multifaceted regimes' global governance. 
At this critical moment, the leadership of General Secretary Xi Jinping is building a constantly changing economic environment, called the "new normal" and intended to stabilize without pursuing high growth. Xi Jinping proposed a 'China's Great Revival Dream' and launched the 2013 'Belt and Road' initiative. BRI was included in the "Thirteen Five-Year Plan (2016-020)" and the $19^{\text {th }}$ Party Congress party constitution in 2017, it is considered China's enormous open-up reform policy.

- What impact does the Belt and Road Initiative have on opening up China?

- What effect does the Belt and Road Initiative have on the world economy and the international trade system?

- How does the Belt and Road Initiative contribute to global governance?

- What approach has BRI implemented in terms of foreign exchange, investment, and finance climate for the participating economies?

- How does BRI interconnect with foreign trade, with the international economic system and thus involve a BRI investment and finance program?

The article organization's as follows. The second section discusses the major international economic regimes and the reaction of China. Third section analyzes China's relationship with the countries along with the "Belt and Road". In the fourth section, the case study of China's attitude towards the international economic system alongside the "Belt and Road" has been discussed. The fifth section, using the gravity model in international trade, addresses the commercial relationship between BRI and the participating countries. The study concludes that cross-border financial cooperation between government and business participants is necessary for the creation of a productive investment and funding system for the BRI. It reiterated the importance of using regional and international financial centers to set up a regional structure within the investment and financing mechanism called "Belt and Road".

\section{Strengthening China's Global Governance}

\subsection{China's Global and Regional Economic Structure}

China's foreign policy strategy mainly guides its opening-up strategy. Traditionally Chinese diplomacy is focused on bilateral relations among independent countries. With the establishment of "Asia-Pacific Economic Cooperation (APEC),"accession negotiations with the "World Trade Organization (WTO)" and liberalization of the Asian currency crisis and facilitation of trade and investment in the 1990s, China's negotiations have reached a new international diplomatic field (Goh, E. 2016). Therefore, given that economic diplomacy is usually not appropriate for bilateral relations, China has only the option of resorting to multilateral ties.

China has widened its openness to the outside world and expressed its thoughts on a new international economic order since joining the World Trade Organization. But today, as the Maoists put it in the 1970s, China's aim isn't to create a new international economic order. In addition to not engaging in the process of setting up major international organizations and institutions immediately after World War II, after opening up to the outside world, the People's Republic of China has no option but to abide by the new multilateral structure. China is feeling incompatible with the current multilateral regimes as it pushes toward economic dominance (Medeiros, E. S. 2019).

\subsection{Challenges to the World Economic Order}

Following the fall of Lehman Brothers, the Ministry of Commerce Research Institute noted the shift in China's opening-up strategy in "Research on China's Foreign Trade Policy for Growth after the Crises" (Breslin, S. 2013). This study explicitly states the transition from raising the trade volume to enhancing productivity and encouraging multilateral, national economic cooperation. After the Lehman shock, a proposal was made that China's economic policy would shift from a passive body to an active participant in international economic order planning worldwide (Ravenhill, J. 2017). The study encourages proactive action in formulating international trade rules, playing a leading role in regional integration and globalization, and expanding the impact of significant commodity prices on the development. China holds this position on foreign trade and economic policies because it was unable to bring about any substantial change in existing multilateral structures. Yet, after the Lehman shock, it contributed to the world economy. This status prevented China from increasing its international standing; somewhat, it was frustrated by the fact that it was not interested in the determination of resource prices, although it had an enormous demand for them.

In China's diplomacy, the instructions given to "TaoGuangyanghui" ("hidden power and waiting time") by top leader Deng Xiaoping were initiated for analysis. In July 2009, President Hu Jintao found the term post-global changes to the financial crisis a diplomatic opportunity and drew the attention of the diplomatic mission to take 
constructive action while firmly following the principles of the "11th Conference of Chinese Diplomatic Envoys Stationed Abroad". China's contribution to international economic global governance has steadily increased with the rethinking of foreign policy principles. To recognize the "Chinese Dream of Grand Rejuvenation" and question the existing international economic order, in order to explore a secure international climate for a global superpower and improve its international standing, China has taken measures (Kerr, D. 2015).

\subsection{The Chinese Contribution to International Multilateral Regimes}

China has launched numerous "exit, voice, loyalty" programs for the current global multilateral structure according to the "hardness" and cost of the transition of each structure (Ohashi, H. (2015). Concerning relatively stable multilateral economic policies, for example, trade, currency, etc., given the enormous cost of restoring order, it is virtually out of the question for China to establish a new multilateral system and adopt the current policy alone. Consequently, China appears to be seeking a reduction in the responsibilities expected under the new guidelines, while continuing to maintain and extend the influence of developing new international norms, rules, and instructions (Rolland, N. 2017).

\subsubsection{International Trade Regime: A WTO G7}

China joined the World Trade Organization (WTO) in late 2001 and became a member of the General Tariffs and Trade (GATT) in 1986. The WTO is seen as the last big international body inaccessible to China. WTO accession means China has been widely recognized by the international community, which tends to be more critical from the perspective of global politics and diplomacy (Mazarr, M. J. et al. 2018). However, China's accession to the WTO has much more substantial economic significance. Chinese foreign trade has grown at a rate of 20-30 percent annually since joining the WTO (Luolin, W. 2015). Since 2009 China has maintained its status as the world's largest exporter and second-largest importer. Chinese FDI, which was expected to join the WTO in the late 1990s, increased significantly to US\$ 50 billion in 2002 and US\$ 100 billion in 2010 and is presently the second largest foreign direct investment recipient in the world (Meltzer, J. P., \& Shenai, N. (2019).

After joining the WTO, China has not tried to reform the existing international trading system; instead, wants to strengthen its standing within the current framework. China is endeavoring to retain its position and to exert a strong impact on WTO decisions. China has received wide-ranging support, especially from developed countries such as the G77 and the G20 (mainly the development community), which are among the major opponents of the WTO.

Decisions of the WTO shall be made at different levels: (i) official conferences, (ii) informal meetings, (iii) green room meetings, and (iv) the members' central meeting. By the end of the $20^{\text {th }}$ century, just before the "Doha Development Round of the WTO", the most powerful committee of WTO members was called the Quartet, comprising Canada, Japan, the European Union (EU), and the USA. At the beginning of the $21^{\text {st }}$ century, however, the G6 has named the largest conference of members, consisting of Australia, Brazil, the European Union, India, Japan, and the United States (Kwaśnicki, W. 2011).

The WTO Informal Ministerial Meeting"took place in July 2008, when China joined the WTO meeting of significant member states as a major exporter in the world and set up a WTO Group of 7 (Hopewell, K., 2015). China has since been actively involved in changing the foreign trade system and rules, helping highly indebted nations, developing countries, and international organizations. Besides, since 2015, China has been the WTO's second-largest donor followed by United States. China is strongly committed to safeguarding and improving its international reputation. Hence, China aims to become a member of the critical member meeting and prioritizes leadership development within the WTO framework (Ibid: 321).

\subsubsection{Economic Monetary Regime}

The US also points out that the Chinese currency renminbi (RMB) undervaluation is a significant cause of China's trade surplus. The United States introduced the Schumer-Graham bill in 2005. Congress, seeking to place a tariff of $27.5 \%$ on goods imported from China if the RMB exchange rate does not increase. However, China embarked on currency reforms in July 2005 to explain the RMB appreciation strategy. Indeed, the decision of the People's Bank of China did not bow to American coercion. China faced an excess liquidity crisis in the mid-2000s as a result of rising current account surplus and foreign exchange reserves. The modification of the exchange rate is seen as an essential economic management policy tool to combat inflation. Consequently, the appreciation of the Renminbi was observed around 50 percent from 2005 to 2015. (Note 1) In May 2015, the IMF declared during the annual IMF-China talks that the RMB will no longer be undervalued (IMF, 2015).

During 2015, a simultaneous contraction was reported in both equity and currency markets in the global economy (UNCTAD, 2017). The disorder in the money market is due to the lack of dialogue with the economy; to make the 
Renminbi enter the Special Drawing Rights (SDR) basket of the International Monetary Fund (composed of the US Dollar, the Euro, the Yen, and the Pound Sterling) (Ibid: 13). Basket currencies with SDR wanted the criteria clarified. The former has been the export rate in the last five years, while the latter is the freely available currency. In October 2015, it was categorically agreed that RMB would become one of the constituent currencies of the SDR in October 2016, thus doubting the second criteria at the same time. In these circumstances, the leadership of the multilateral monetary system has once again been given priority by China.

\subsubsection{Universal Umbrella Regime: From Negative to Constructive}

China may act by 'speech' or 'exit' against 'immature' or developing multilateral regimes, not to mention China's division and aggression in the South China Sea (i.e., the international maritime administration), it naturally grows in global systems such as cyberspace, space development, bioethics, technical standardization, and development aid/financing. (Section 4 of this paper looks in depth at the development aid/financing system).

As regards environmental regimes, on "15 th Conference of the Parties to the United National Framework Convention on Climate Change (COP 15)," held in Copenhagen in 2009, an agreement was initiated by the developed countries between emerging and developing countries to minimize emissions (Doelle, M. 2010). On the other side, emerging economies (including China) accept that developed countries should be kept accountable for global warming (which can be traced back to the (Industrial Revolution) and thus vigorously deny the obligations of developing countries (Samuel F. Nicholas, S, 2016). The reason for their resistance is that they are legally bound and responsible for increasing greenhouse gasses would constrain energy usage and hamper the growth of emerging economies. Subsequently, China established a negotiating coalition known as "the Easy" with South Africa Brazil and India (Hochstetler, K. A. 2012). China also took the initiative as the G77 spokesman and strongly opposed the request of the other members to reduce greenhouse gases.

Nevertheless, the two main greenhouse gas emitters, such as the United States and China, agreed to implement a new international mechanism to assess global warming in response to the 2015 Paris Climate Change Control Agreement (Gao, Y., Gao, X., \& Zhang, X. 2017). For the first time in the history of the Paris Agreement, both countries have to address the greenhouse gas mitigation problem. China is playing the role of a "responsible superpower" in the international community in the current global warming situation, and President Trump has announced the withdrawal of the United States from the Paris Agreement (June 2017), keeping his key campaign compromised. The discussion mentioned above shows that, according to the problem domain, China's position on multilateral regimes varies, but its commitments to these issues are gradually increasing.

\section{Nexus between China and Countries Involved in "Belt and Road"}

\subsection{BRI Theory, Action, and the Contribution of China}

China's President XI Jinping proposed the development of the Silk Road Economic Belt in September 2013 and the 21st Century Maritime Silk Road, now known as the "Belt and Road Initiative". This project has received comprehensive coverage from the global media and reliable feedback from the countries concerned. It is a combination of today's demand and the ancient Silk Road historical symbols. This project aimed at fostering international cooperation, enhancing intercultural ties, and sustaining world peace, security, and stability. It shows that China, as the largest developing country in the world and the second-largest economy, bears a broad range of responsibilities in promoting the progress of international economic governance towards an equal, impartial, and sustainable structure.

Before the "Belt and Road" International Cooperation Summit Forum, China, as the sponsoring country, published "Building the Belt and Road: Concepts, Practice and Chinese Contribution" to enhance the understanding of the initiative by the international community, its benefits and promoting strategic mutual obligation, dialogue and cooperation between countries. China aims to make new and growing contributions to creating a mutually vocated, peaceful society.

BRI is seen as counteracting the "rebalancing policy" in the United States. Around the same time, some people in China were challenging the "Westward" policy, which is an expansion of the "West Growth" (Zheng, Y. 2020). Conflict with the United States is necessary if we are to improve our growth in the Asia-Pacific region. Entering the Eurasian Region and creating new markets is a trend leading to a cooperative partnership with the US. Since the Trump administration came to power, China's perceptions of the United States on Western democracy's fundamental principles have also drastically shifted.

The export-oriented Chinese economy, in the initial days of opening up to the world, has significant importance for the US market, but entering the US market is simpler than ever, and Chinese goods are rarely rejected due to the rise of US trade protectionism. The "Belt and Road" project aimed at Eurasia is also a new idea for China's 
economic diplomacy, despite the US market's plight.

\subsection{BRI Overview}

In 2013, President Xi Jinping announced an important strategic component of China's "Go Global" policy is the Belt and Road Initiative (Alam, M. M. 2014). The movement derived from the ideology of the ancient Chinese "Silk Road Spirit" and promoted fostering harmony, collaboration, transparency, equality, mutual learning, and collective benefits for all nations (Xihua, 2015). The "Belt and Road" project is widely seen as a game-changer for Asian, European, and African landlocked economies. The "Belt and Road" is a busy road and rail network that links Western China via Central Asia, Iran, Turkey, Russia, the Caucasus, and the Balkans to Western Europe. Through connecting Eurasia by land, it was also proposed that the "2 ${ }^{\text {st }}$ Century Maritime Silk Road" connect China to South Asia, Southeast Asia, Middle East, Africa, and Europe via the South China Sea, the Indian Ocean and the Mediterranean Sea (Pencea, S. 2017; Rolland, N. 2017).

The Chinese Government is committed to the construction of six economic corridors: 1) China-Pakistan Economic Corridor; 2) China-Indochina Peninsula Economic Corridor; 3) Bangladesh-China-India-Myanmar Economic Corridor; 4) China-Mongolia-Russia Economic Corridor; 5) China-Central Asia and Western Asia Economic Corridor; 6) and the new Eurasian Continental Bridge and Oil and Gas Pipeline Parallel Network. Chinese establishments find that transportation infrastructure is "the first step towards building an economic corridor that will integrate the Eurasian hinterland's landlocked economies and bring them closer to China" (Rolland, N. 2017).

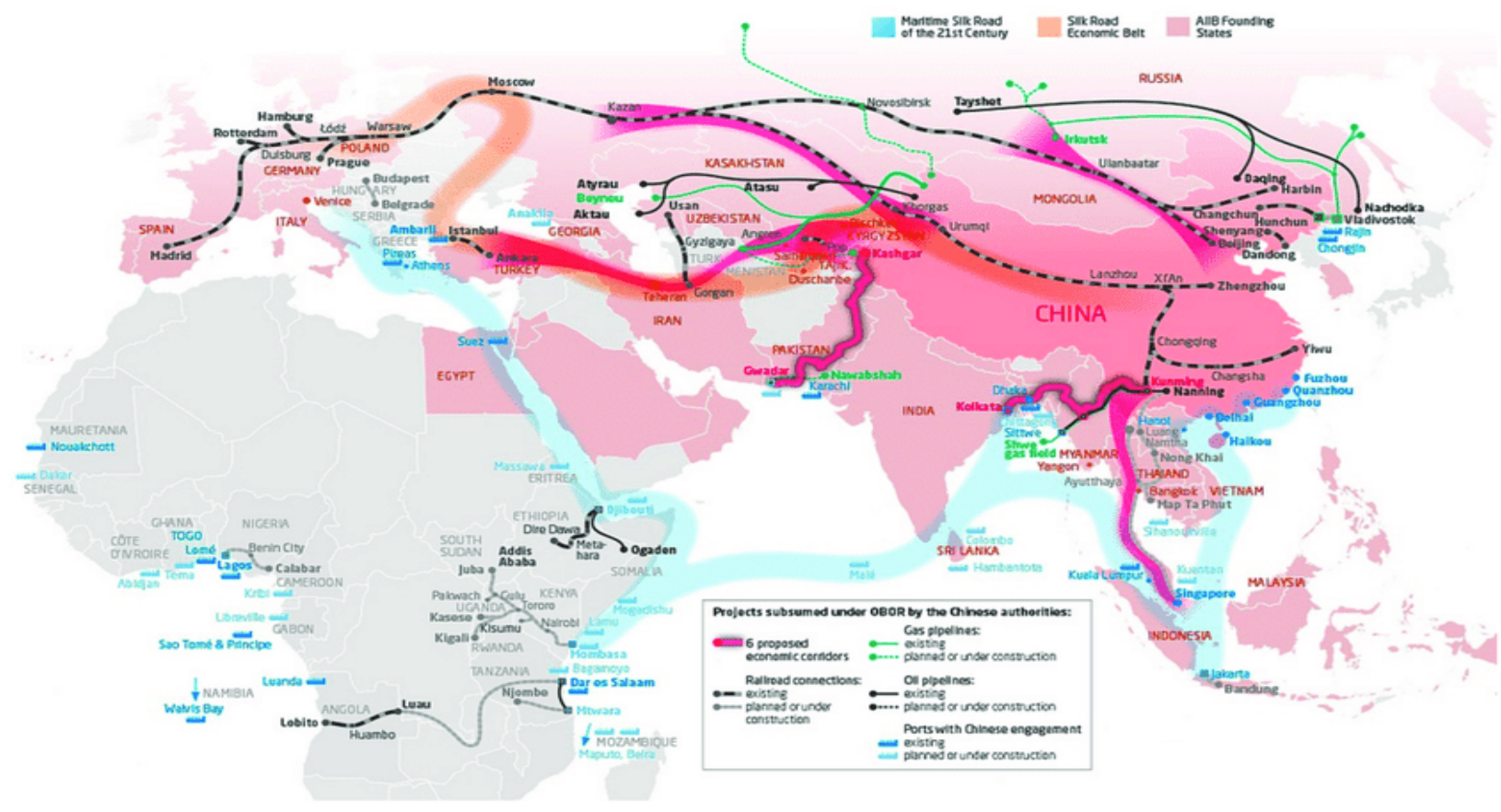

Figure 1. China's Belt and Road Initiative (BRI) Map

Source: Mercator Institute of China Study, 2015

BRI's strategic value to China could be seen from the substantial US $\$ 1$ trillion allocations to launch this project in 2013. Moreover, this initiative has attracted US\$ 8 trillion to promote the creation of an infrastructure in BRI participating countries, especially from Asia. China has included the 'Belt and Road' plan in its constitution at the end of 2017 to find more international recognition (Brown, K. 2018; Callahan, W. A. 2016). Chinese scholars believe the "Belt and Road" initiative is not limited to infrastructure development; it will also trigger inter-country policy and cultural exchanges. BRI would encourage network connectivity, facilitate free trade, and raise financial support to developed countries, eventually strengthening China's reputation as a responsible emerging global state (Jin, X., Li, D., \& Wu, S. 2016; Mohieldin, M, 2017). In reality, China is planning to establish a comprehensive communication and connectivity strategy "from politics to economy, from infrastructure and commerce to culture and religion, to building economic cooperation zones and cultural exchange centres" (Jia, W. 2017).

The BRI is a long-term commitment that involves a collective effort to work together to achieve a more inclusive 
and organized production from all participating countries. Across developing countries, the scarcity of financial resources and infrastructure is a precondition for economic and industrial growth (Bei, J. 2017). With more than US\$ 3.5 trillion in foreign-exchange reserves, China has rich experience in financial capital and infrastructure development. The "Belt and Road" initiative thus promises the development of large-scale infrastructure, laying the cornerstone for economic and industrial affluence in the Region (Lai, T. L., Tang, J., \& Yin, H. 2018). Projects linked to the 'Belt and Road' initiative comprise $70 \%$ of the world's population, $75 \%$ of known oil, reserves and territories, $25 \%$ of global trade, and 55\% of global GDP (Khan, M. K. et al., 2018).

\subsection{Establishment of an Economic Region Controlled by China}

The BRI's principal objective is to create new markets, raise foreign investment, reduce overcapacity, revitalize the regional economy, internationalize RMB, and foster neighborhood diplomacy. Given the diversification of international trade and increased foreign investment, there is no doubt that China, undoubtedly China, as the second-largest economy in the world, is trying to protect its interests and create new conditions in which China's participation in economic activities would be easy. The "Belt and Road" initiative's fundamental aim is to create a Chinese economic zone so that it can scarcely compete with other economic forces. BRI is an essential component for the growth of regional infrastructure and works in the creation of the economic domain. Highways, railroads, and ports are unique BRI programs.

After that, the first freight train between China and Europe gained attention worldwide. It has handled more than 5000 cargoes by September 2017 since its opening in 2011 and has linked 33 cities in China and 33 cities from 12 European countries. Most goods are currently produced in China using information technology (IT) related items. These products include personal computers, and cell phones, however the products sold are diverse, including food, clothes, wood and furniture, vehicles and parts, machinery and heavy equipment (Woetzel, J. (2019). Chinese firms, along with other various industries, have a strategic edge in the construction and infrastructure growth market. The initiative "Belt and Road" put out sheer possibilities for the numerous sectors related to manufacturing, construction, and infrastructure in China. Currently, the massive demand for infrastructure development and networks has simultaneously attracted the rest of the world; there are significant concerns about the risks of feasibility and execution, whether such ventures are viable (Xihua, 2015).

Since 2009, China has been slowly lifting restrictions on the use of RMB in transactions across borders. Use of RMB has shown a rapid growth of significant cross-border developments in finance, foreign trade, and financial transactions. The Renminbi is currently the third-largest trade finance currency in the world and the fifth-largest payment and exchange currency in the world. The active promotion and internationalization of RMB and crossborder use is an essential precondition for the execution of the "Belt and Road" initiative and a necessary foundation for the purpose-fitting construction of BRI investment and financing framework. More precisely, it will convince the Chinese department and encourage participating BRI countries to become a member of BRI, which will undoubtedly increase the size of trade and investment ties. Allowing businesses in Chinese currency such as the Renminbi will escape commodity gains and losses resulting from US dollar fluctuations, thus optimizing the security of countries' income along with the "Belt and Road" (Dunford, M., \& Liu, W. 2019).

\subsection{International Financial Institutions Development}

China has taken the view seriously that successful financing is central to the implementation of the 'Belt and Road' initiative. Also, China has established financial development institutions such as the Silk Road Fund and the Asian Infrastructure Investment Bank (AIIB), previously known as the BRICS Development Bank, the New Development Bank (NBD).

In the midst of this, the Asian Investment Bank was set up in January 2016, catching people's interest because this is China's first international financial development agency. China accounted for 29.4 percent of the overall capital invested as of December 2017 (AIIB, 2017). AIB has 84 members so far, far more the 67 members of the "Asian Development Bank (ADB)," which dominated the construction of Asian infrastructure. The biggest owners are Japan and the United States, accounting for 15.6 percent (ADB, 2019). During the previous two years, the Asian Investment Bank has invested in 24 projects in 12 countries, with a total loan of US\$ 4.2 billion (Renminwang, 2018). In June 2017, AIIB was awarded the Moody's triple-A rating, followed by the Fitch rating and the Good \& Poor rating in July 2017 (AIIB, 2017), it is considered an exceptional opportunity to raise funds and is regarded as an unresolved problem, and has also grown considerably.

The AIIB's objective is to manage it quickly and economically and to be aligned with developing countries. Since Chinese development aid/finance is sometimes criticized as "new colonialism" (Mohan, G. \& Power, M. 2008). Several concerns arise as to whether the infrastructure projects of the AIIB should completely recognize environmental and social factors and whether the benefits can be assured to the exceeded costs. However, 
commemorating the previous few years after its establishment, most of the Asian Investment Bank's businesses are joint venture-based with the WB and ADB.

The Asian Investment Bank and the "Silk Road Fund", the "Chinese Export-Import Bank", and the "China Development Bank" also control development aid/financing but are intended to generate benefits. Additionally, the Asian Development Bank's primary focus is on soft loans and company auxiliaries. The following discussion highlights that China is expanding its development aid/financing roles, considering the creation of the Asian Investment Bank and the Silk Road Fund, which can be seen as one of China's provocations towards the current multilateral economic regimes.

\subsection{Globalization of $R M B$}

Since the effect of the Lehman shock, China has been encouraging the RMB's internationalization to avoid overreliance on the US dollar, intending to create an area dominated by long-term RMBs. By increasing the RMBbased trade and economic activity of foreign direct investment, liberalizing interest rates, rising capital controls, extending currency swap deals, and lending assistance to RMB. China aims to meet the conditions required for RMB to become a leading foreign currency, reflecting currency unit, methods of payment, and value storage. From 2010 to 2015, the proportion of RMB-denominated transactions in China's total trade rose from 2.4 percent to 22.8 percent, reflecting the steady evolution of RMB internationalization. According to Statistics from the Global Interbank Financial Telecommunications Association (SWIFT), in December 2017, the RMB transaction amount accounted for just $1.75 \%$ of the overall foreign transaction, much smaller than the Japanese yen $(2.62 \%)$ and the Canadian dollar (1.93\%), the Euro (32.62\%) and the British pound (7.42\%). (Note 2)

To promote the process of internationalization, the RMB must be internationally trustworthy, convertible, and globally tradable. Nonetheless, if the RMB circulation area is limited, BRI participating countries would increase RMB's relative position. Projects denominated in RMB will surely increase investment and financial transactions, and countries along the "Belt and Road" will gradually embrace this with the stability or appreciation of the RMB exchange rate. With the creation of BRI, an "RMB currency region" may be formed spontaneously, covering several/most of the "Belt and Road" countries.

\subsection{Industrial Adaption Technology}

The 'Belt and Road' initiative provides a beneficial opportunity for the development of new markets for Chinese industries or some industries with additional resources for industrial change. In China, the policy of dealing with overcapacity adjustment and persuading the move of declining industries abroad is called "foreign collaboration on industrial capacities." In 2015, this strategy led the State Council to issue a list of industry goals (Ordóñez de Pablos, P. (Ed.). 2016). (2016).

The first sector relates to infrastructure (building, manufacture of vehicles, and construction materials). Many of the BRI participating countries are emerging and transition economies and have tremendous infrastructure growth potential, providing numerous opportunities not only for the moderate industry in China but also for overcapacity in the subset of the industry. Furthermore, a list of specified industries, such as the development and operation of dry ports, airports, roads and railways, manufacturing, and logistics of their relevant facilities, have been considered the most significant.

Natural resources and electricity are essential. Severl BRI participating countries are well equipped and are full of natural resources. Strategically China aims to secure reliable energy supply and extend energy transportation routes. Besides, the BRI participating countries have ample market opportunities in oil and gas pipelines, power building, refineries, and equipment manufacturing links. Overseas projects funded by Chinese civil engineering/construction firms are the third priority sector. Compared to other businesses, they have excellent foreign visibility, and these companies are aggressively creating new markets across the globe. Such construction companies have undertaken various projects in the BRI participating countries.

For the Chinese industrial enterprises to successfully move their factories across borders, the development of the industrial sector and overseas economic and commercial cooperation zones for their adoption and the provision of infrastructure and public services are unavoidable. As of 2016, 77 parks and zones were developed and operated in 36 countries/regions worldwide. These companies' overall investment reached US\$ 24.19 billion, with 1,522 business occupants, with total revenue of US\$ 70.28 billion, tax payments to the host country of US $\$ 2.67$ billion, and 212,000 local employees are provided jobs. Approximately 56 parks and zones were developed in 20 Developing nations, with a total expenditure of $\$ 18.55$ billion, 1082 residents, a total income of $\$ 50.69$ billion, and $\$ 1070$ million taxes paid to the host country, and 177,000 local workers were provided with employment. (Gong, X. 2020). Based on the fact that more than 70 percent of China's international economic and trade 
cooperation zones are located in participating countries of the BRI, the BRI's aim is to significantly enhance its role in China's opening-up policy.

\subsection{Economic Ties with the BRI Participating States}

Notwithstanding the global attention given to the "Belt and Road" initiative, China's economic relationship with the BRI countries has just begun. As reported in the 2017 China customs statistics, the total amount of imports and exports between China and the BRI countries was RMB 7.37 trillion, a growth of 17.8 percent over the previous years; exports amounted to RMB 4.30 trillion (an increase of 12.1 percent), and imports were RMB 3.07 trillion (an increase of 26.8 percent), representing 26.5 percent of total Chinese imports and exposures. Besides, China was, in the same year, the largest trading partner of 16 neighboring countries (Renminwang, 2018).

Commodity trade has also reached a broad scale amongst China and the BRI members countries. The BRI nations, however, account for just 8-13 percent of China's foreign investment (See Table 1). The automotive sector accounts for just 12-18 percent of China's overall foreign investment in international industrial capacity cooperation. China has strictly controlled capital spending, with foreign investment declining dramatically during the 2016-17 fiscal year. However, in 2017, Chinese companies completed 62 mergers and acquisitions (M\&A) in BRI countries for a total of US\$ 8.8 billion (an increase of 32.5 percent over the previous year). This acquisition includes 12 percent ( $\$ 2.8$ billion) interest in Abu Dhabi Petroleum in the United Arab Emirates by PetroChina and China Huaxin Investment (M\&A Report China, 2020). As the investment environment of BRI member countries improves, the economic relationship amongst China and these countries will become more positive. 
Table 1. China's FDI and Building/industrial cooperation with BRI participating Countries [FDI*].

\begin{tabular}{|c|c|c|c|c|c|c|c|c|}
\hline Year & $\begin{array}{c}\text { No. of } \\
\text { Countries }\end{array}$ & $\begin{array}{l}\text { Investment } \\
\text { Value } \\
\text { (\$ billion) }\end{array}$ & $\begin{array}{c}\text { Annual } \\
\text { Increase } \\
(\%)\end{array}$ & \multicolumn{2}{|c|}{ BRI/Total (\%) } & \multicolumn{3}{|c|}{ Major destinations } \\
\hline 2015 & 49 & 14.82 & 18.2 & \multicolumn{2}{|c|}{10.2} & \multicolumn{3}{|c|}{$\begin{array}{c}\text { Singapore, Kazakhstan, Laos, } \\
\text { Indonesia, Russia, Thailand }\end{array}$} \\
\hline 2016 & 53 & 14.53 & -2.0 & \multicolumn{2}{|c|}{8.5} & \multicolumn{3}{|c|}{$\begin{array}{c}\text { Singapore, Indonesia, India, Thailand, } \\
\text { Malaysia }\end{array}$} \\
\hline 2017 & 59 & 14.36 & -1.2 & & & \multicolumn{3}{|c|}{$\begin{array}{c}\text { Singapore, Malaysia, Laos, Indonesia, } \\
\text { Pakistan, Vietnam, Russia, UAE, } \\
\text { Cambodia }\end{array}$} \\
\hline 2018 & 55 & 14.9 & 0.2 & & & \multicolumn{3}{|c|}{$\begin{array}{c}\text { Singapore, Laos, Pakistan, Malaysia, } \\
\text { Indonesia, Vietnam, Cambodia and } \\
\text { Thailand. }\end{array}$} \\
\hline \multicolumn{9}{|c|}{ Overseas contracted projects } \\
\hline Year & $\begin{array}{c}\text { No. of } \\
\text { Countries }\end{array}$ & $\begin{array}{l}\text { No. of new } \\
\text { contracts }\end{array}$ & $\begin{array}{l}\text { Contract } \\
\text { value } \\
\text { (\$billion) }\end{array}$ & $\begin{array}{c}\text { Annual } \\
\text { increase } \\
(\%)\end{array}$ & $\begin{array}{c}\text { BRI/total } \\
(\%)\end{array}$ & $\begin{array}{l}\text { Turnover } \\
\text { (\$billion) }\end{array}$ & $\begin{array}{c}\text { Annual } \\
\text { increase } \\
(\%)\end{array}$ & $\begin{array}{c}\text { BRI/total } \\
(\%)\end{array}$ \\
\hline 2015 & 60 & 3,987 & 92.64 & 7.4 & 44.1 & 692.6 & 7.6 & 45.0 \\
\hline 2016 & 61 & 8,158 & 125.03 & 36.0 & 51.6 & 759.7 & 9.7 & 47.7 \\
\hline 2017 & 61 & 7,217 & 144.32 & 14.5 & 54.4 & 855.3 & 12.6 & 50.7 \\
\hline 2018 & 61 & 7,314 & 145.33 & 6.4 & 58.7 & 932.3 & 13.6 & 48.1 \\
\hline
\end{tabular}

International Industrial Capacity Cooperation

\begin{tabular}{ccccccc}
\hline Year & $\begin{array}{c}\text { Manufacturing } \\
\text { industries } \\
\text { (\$billion) }\end{array}$ & $\begin{array}{c}\text { Annual } \\
\text { increase } \\
\mathbf{( \% )}\end{array}$ & $\begin{array}{c}\text { (1)/Outward } \\
\text { FDI (\%) }\end{array}$ & $\begin{array}{c}\text { (2) Facility } \\
\text { manufacturing } \\
\text { industries (\$billion) }\end{array}$ & $\begin{array}{c}\text { Annual } \\
\text { increase } \\
(\%)\end{array}$ & (2)/ (1) (\%) \\
\hline 2015 & 14.33 & 105.9 & 12.1 & 7.04 & 154.2 & 49.1 \\
\hline 2016 & 31.06 & 116.7 & 18.3 & 17.86 & 153.7 & 57.5 \\
\hline 2017 & 19.12 & -38.4 & 15.9 & 10.84 & -39.3 & 56.7 \\
\hline 2018 & 15.23 & -27.4 & 13.3 & 6.06 & 27.4 & 39.8 \\
\hline
\end{tabular}

*FDI in the financial sector is not included

Source: Ministry of Commerce, People's Republic of China (PRC), http://english.mofcom.gov.cn/article/policyrelease/gazette/201903/20190302841016.shtml

The successful participation of Chinese companies in these joint-ventures has rapidly increased their market share in these areas, especially in BRI participating countries. In other words, China's economic relationship with the BRI participating countries is still in its initial phases of infrastructure growth. As China's financial support to countries along the BRI continues to grow, it is expected that infrastructure construction will increase and broaden 
trade and investment relationships among member countries.

Today, China's openness is no longer focused solely on bilateral relationships, such as promoting free trade links with Hong Kong, ties with Japan injecting capital and technology, and expanding US business markets. There is no doubt that China's links with the participating BRI countries are composed of individual bilateral ties, so that they are mostly perceived within the BRI as multilateral foreign relations. Consequently, China has become the second-largest economy in the world through its open-up policy in the new nations and has focused more on multilateral ties than bilateral relations.

\section{A Case of Development Aid/Financing for China}

\subsection{Main Principles}

As its presence has expanded in the field of development aid/finance, China has announced a "white paper" on China's foreign aid to increase its transparency and accountability (Fuchs, A., \& Rudyak, M. 2019). However, the definition and application of the international aid program are fundamentally different from that of the leaders of the OECD "Development Assistance Committee" (DAC), so it is unlikely that the publication will only know the overall foreign trade aid situation of "White Paper" (Shimomura, Y. \& Ohashi, H. (Eds.), 2013).

The fundamental principles of Chinese foreign aid in the following points differ materially from the donor group constituted by DAC leaders (Watanabe, S. 2013). First and foremost, while the donor community is committed to enhancing developing countries' welfare and economic growth, China adheres to its "eight principles of foreign assistance" support ideology. Second, although the donor community conducts development-based assistance from the viewpoint of not intervening in domestic affairs, the implementation of a particular development model is also unfavorable for China. Third, despite the emphasis on high subsidy rates, subsidy components, and free aid from the donor community, China tends to favor loans and tied assistance.

\subsection{Key Achievements}

Foreign aid to China (multilateral cooperation, preferential bilateral loans, and grant aid) reached USD 6.1 billion in 2015 (Kitano, N. 2017). According to DAC estimates, China is the $8^{\text {th }}$ largest donor country in the world, trailing major donor nations like the United States, Germany, the United Kingdom, and Japan, and is more important than major European countries such as Netherlands, Sweden, Norway and emerging donors such as the United Arab Emirates and Saudi Arabia. Though, Chinese development aid/finance, based on the DAC, is defined by economic cooperation and is applied outside the Official Development Assistance (ODA) system. In comparison, the combined assets of China Development Bank (CDB) and CEXIM in 2016 were 3.5 times the assets of the six largest foreign financial cooperation institutions led by the DAC (Bataineh, B., Bennon, M., \& Fukuyama, F. 2018)

The study uses the public knowledge based AidData database (Note 3) (China's global footprint for development) to understand Chinese public financial flows to developing countries (Dreher at al., 2017). Observing patterns after 2000, the annual funding allocated to developing countries exceeds US\$ 30 billion in commitments, of which Official Development Assistance (ODA) exceeds US\$ 5 billion (see figure 2 below). The capital flow in 2009 was substantial because China Development Bank (CDB) provided the Russian oil giant Rosneft (US\$ 20.4 billion) and Transneft (US\$ 13.6 billion) with two major loan projects. 


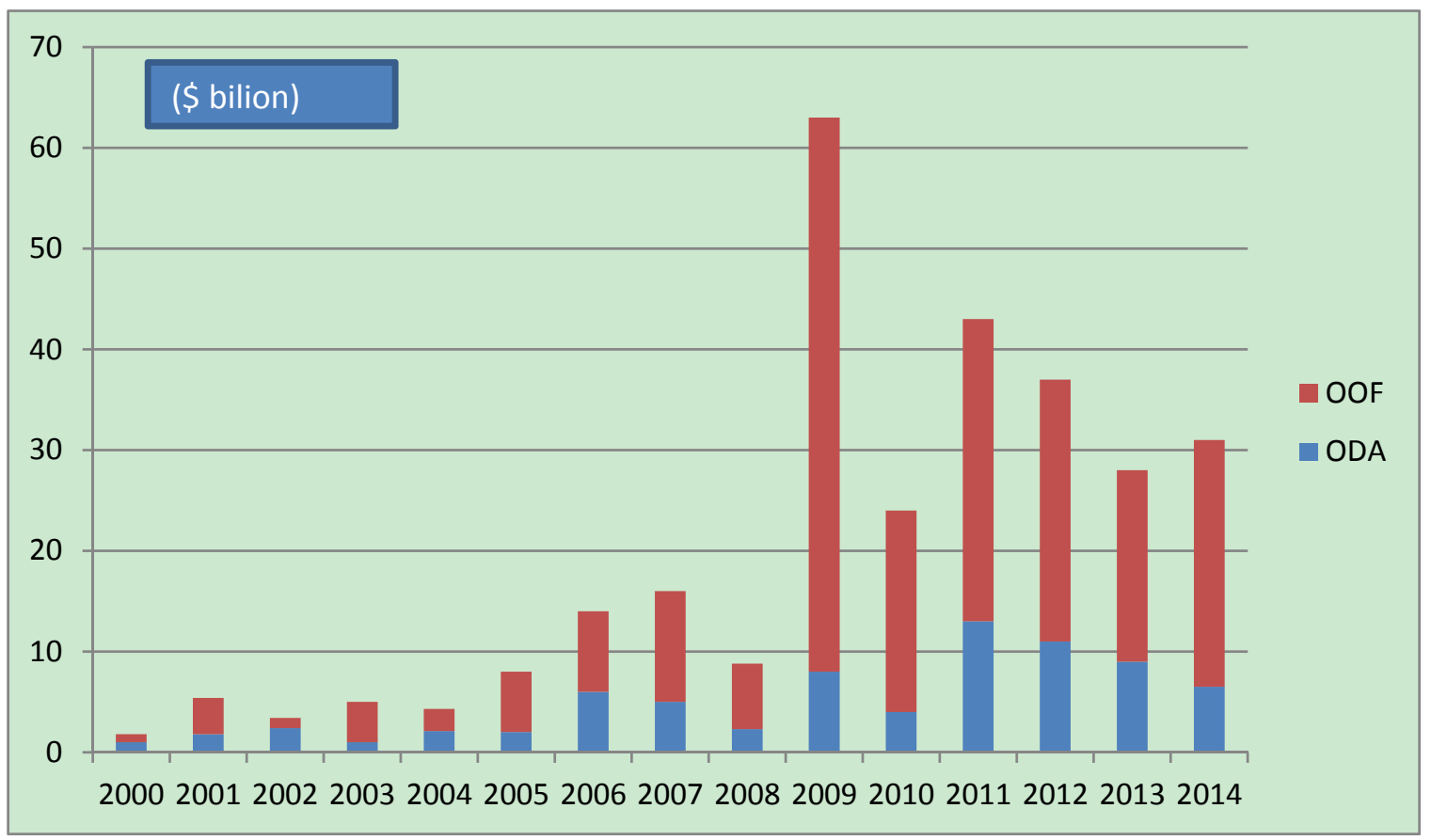

Figure 2. China's Development aid/ finance (2000-2014)

ODA (Official Development Assistance) $=$ grant element of at least $25 \%$

OFA (Other Official Flows) $=$ grant element of at least $25 \%$

Source Calculation was made on the study conducted by Dreher et al., "Aid, China, and Growth."

From an industrial financed project perspective, the most important loans to the energy production sector are made based on OOF rather than ODA, including the loans for Russia listed above (see Table 2 below). There is a demand for transportation and energy production. China's key focus in its development aid/financing and the initiative 'Belt and Road' remained on infrastructure growth. Meanwhile, China's Official Development Assistance (ODA) policy also recognizes the value of debt reduction. The donor group has some questions about that from the viewpoint of aid discipline.

Table 2. China's development aid/ finance by industry (\$billion)

\begin{tabular}{lcccc}
\hline & ODA & OOF & OF & Total \\
\hline Agriculture & 1.4 & 7.5 & 1.1 & 10 \\
Debt remission/rescheduling & 12.3 & -- & 0.7 & 13 \\
Telecom & 4.1 & 10.8 & 2.0 & 16.9 \\
Mining/ Construction & 4.4 & 22.3 & 3.6 & 30.3 \\
Transportation & 23.1 & 37.7 & 28.0 & 88.8 \\
Energy & 11.3 & 109.3 & 13.5 & 134.1 \\
Other & 24.5 & 28.8 & 8.0 & 61.3 \\
\hline
\end{tabular}

* No information found regarding the concessionality level for OF (Official Finance)

Source: Author's own compilations based on Dreher et al., "Aid, China, and Growth."

There are no geographic characteristics of the Chinese development aid/finance recipients (as shown in Table 3). As of 2014, the project-based database makes development aid/financing for African countries still significant, and no specific focus was put on countries along the "Belt and Road" by then. As can be seen from the countries' overseas ventures along the "Belt and Road", however, they tend to have become core areas of China's development 
aid/finance.

Table 3. Major recipients of China's development aid/ finance

\begin{tabular}{cccccc}
\hline \multicolumn{1}{c}{ ODA } & \multicolumn{2}{c}{ OOF } & \multicolumn{2}{c}{ Number of Projects } \\
\hline Country & \$billion & Country & \$billion & Country & No. \\
\hline Cuba & 6.7 & Russia & 36.6 & Cambodia & 168 \\
Cote D'ivoire & 4.0 & Pakistan & 16.3 & Pakistan & 121 \\
Ethiopia & 3.7 & Angola & 13.4 & Zimbabwe & 120 \\
Zimbabwe & 3.6 & Laos & 11.0 & Angola & 110 \\
Cameroon & 3.4 & Venezuela & 10.8 & Sudan & 108 \\
Nigeria & 3.1 & Turkmenistan & 10.1 & Tanzania & 101 \\
Tanzania & 3.0 & Ecuador & 9.7 & Ghana & 95 \\
Cambodia & 3.0 & Brazil & 8.5 & Kenya & 89 \\
Sri Lanka & 2.8 & Sri Lanka & 8.2 & Ethiopia & 88 \\
Ghana & 2.5 & Kazakhstan & 6.7 & Sri Lanka & 86 \\
\hline
\end{tabular}

Source: Data compiled on from the study of Dreher et al., "Aid, China, and Growth."

\subsection{Relationship with the Current Regimes}

The donor community is anxious about Chinese development aid/ funding for developing countries.

First, China's development aid/financing typically has little interest in risk management, as it mainly takes the form of public finance and liquidity. According to the national risk indicator regularly published by international rating agencies, it can be determined that repaying large amounts of Chinese funds that flow to developing countries is becoming increasingly challenging. Moreover, the investment risks, there are operational risks after the completion of the project, and it can also be challenging to repay the debt of the developing countries to China (Dollar, D. 2018).

Second, due to a large volume of capital flows from China, developing countries can face debt crises. Developing countries typically seek support from the International Monetary Fund (IMF) and fall into the debt crisis. In response to this demand, if the IMF decides to assist debt crisis countries, Chinese development aid/financing may directly add to the pressure on the IMF. Following a comprehensive risk assessment by developing countries, China needs to implement development aid/financing.

Third, the Chinese relationship to existing financing institutions for development is very delicate. The Chinese capital has turned into an additional channel for capital flowing into developing countries. Those countries will have more options for economic development, but with the help of the IMF and the World Bank, the implementation of policy conditions is required for those developing countries, etc., to refuse to implement policy conditions, it is possible to respond unilaterally to Chinese money. When it comes to stressing the policy conditions during the Structural Adjustment Loans (SAL) period, reciprocating assistance inevitably requires market-oriented economic and structural reforms. Nonetheless, the basic norms of the DAC member, for example, enhancing accountability, performing obligations, and carrying out anti-corruption activities, are also regarded as policy conditions. Ideologically, these views may be difficult to align with the fundamental tenets of China's development aid/finance.

There has so far been no indication that China plans to improve the existing program of financial/ development aid. Indeed, the current development aid/financial system could be problematic due to the strong demand for the Chinese currency. Developing states have, for a long time, increased their share of resources in the financial institutions for international development and expanded their voting rights in those institutions. They have been described as critical problems in the new foreign aid and development finance system but have not been realized. Therefore, China's creation of the AIIB is a very significant task, as it is not feasible to fulfill the development aid/financing for the infrastructure needs of developing countries currently given by DAC members. It also shows how substantial economic growth is for the development of infrastructure in developing countries. If current DAC member countries' development aid/financing for the developing countries is not successful, a series of Chinese 
policy initiatives would be seen as a new threat to current development aid/financing. The strategy of the 'Belt and Road' initiative aimed at China is to establish connectivity and cooperation between the six major economic corridors, including China and; 1) Mongolia and Russia; 2) Eurasian countries; 3) Central and Western Asia; 4) Pakistan; 5) other Indian subcontinent countries; 6) and Indochina. Asia needs US\$ 26 trillion to build infrastructure by 2030 , and China will contribute some of that massive investment (Ra, S. \& Li, Z. 2018). The investment made by the construction of the infrastructure has had a positive effect on the countries concerned. Mutual gain is a distinct feature of the BRI, which, in the long run, will help grow the Chinese product market and, in the short term, reduce the excess industrial capacity. BRI gives priority first to hardware (infrastructure) and financing. The next chapter highlights the relevance of this study with respect to Chinese development aid/finance in the BRI participating economies and some of the consequences for these countries.

\section{Conclusion}

In October 2017 Political Report at the $19^{\text {th }}$ Party Congress, General Secretary Xi Jinping set a new target for China to become the "great modern socialist country" by the middle of the twenty-first century, and proposed to promote the building of a "community of shared future for mankind". During the conference, Xi Jinping announced that "standing firm on national sovereignty, security, and development interests, we will actively engage and lead the reform of global governance and open up a new phase of great power diplomacy with Chinese characteristics". In this context, the BRI is seen as a practice of building a community of shared future for humanity.

Under the leadership of the Xi Jinping government, China's opening-up policy no longer implies developing unique bilateral relationships and enforcing clear requirements for foreign exchange and technology, but a response as an economic superpower to multilateral international relations. In the near future, China's presence in global governance appears to be gradually enhanced. At the moment, China is likely to be a proponent of reforms in global multilateral relations by taking a leadership role within the system rather than questioning the current international framework.

As described above, China appears to go its own way with respect to multilateral regimes in the creative stage. The alliance between China and the "Belt and Road" countries is also a place to try to establish a China-led economic zone. In reality, however, with the success of the "Belt and Road" project, some "Belt and Road" countries are still frustrated with the delay of China's project and the enormous debt to China.

The perception of China as a "threat" to the world is growing. China, as an emerging superpower, would establish an exclusive "Belt and Road"-based economic zone and become a new global rule-maker, not the G7 which makes it a threat. Via ties with countries along the "Belt and Road" and considering the current development aid / financial system, I have come to the conclusion that China's capacity and ambition to set new global norms and rules are still limited (even if China continues to follow its own route). China is likely to remain in that sense what Shambaugh calls a "partial force" (Shambaugh, D.L. 2013).

By adopting an open policy, China can operate the world's free trade system almost openly, thereby benefiting from trade and foreign direct investment. In the future, China will likely reap these advantages with a strain on reduced costs of being a law maker. Ironically, recent trends to weaken a system of free trade with increasing protectionism are not inherently beneficial to China. The most favorable situation for China is to continue to use the benefits of the free trade system while developing a backyard economic zone led by China and countries along the Belt and Road.

\section{References}

AIIB Annual Report and Financials. (2018). Beijing: Asian Infrastructure Investment Bank. Retrieved June 2, 2020, from https://www.aiib.org/en/news-events/news/2017/annual-report/highlights.html

Alam, M. M. (2014). China's Changing Strategic Engagements in Central Asia. Journal of Central Asian Studies, 21(1).

Asian Development Bank (ADB). (2019). Annual Report. Retrieved June 3, 2020, from https://www.adb.org/sites/default/files/institutional-document/603881/adb-annual-report-2019.pdf

Asian Infrastructure Investment Bank. "2017 at a Glance." In Financing Asia's Future: 2017

Bataineh, B., Bennon, M., \& Fukuyama, F. (2018). Beijing's building boom: how the West surrendered global infrastructure development to China. Foreign Affairs, 21.

Bei, J. (2017). Economic Globalization 3.0 and the Concept of Interconnection under the belt and road initiative. China Economist, 12(2), 2.

Breslin, S. (2013). China and the global order: signalling threat or friendship?. International Affairs, 89(3), 615- 
634. https://doi.org/10.1111/1468-2346.12036

Brown, K. (2018). The Belt and Road: Security Dimensions. Asia Eur. J., 16, $213-222$. https://doi.org/10.1007/s10308-018-0514-9

Callahan, W. A. (2016). China's "Asia Dream" the belt road initiative and the new regional order. Asian Journal of Comparative Politics, 1(3), 226-243. https://doi.org/10.1177/2057891116647806

Doelle, M. (2010). The legacy of the climate talks in Copenhagen: Hopenhagen or Brokenhagen. Carbon \& Climate L. Rev., 86. https://doi.org/10.21552/CCLR/2010/1/132

Dollar, D. (2018). Is China's development finance a challenge to the international order?. Asian Economic Policy Review, 13(2), 283-298. https://doi.org/10.1111/aepr.12229

Dreher, A., Fuchs, A., Parks, B., Strange, A., \& Tierney, M. J. (2017). Aid, China, and growth: Evidence from a new global development finance dataset. https://oi.org/10.2139/ssrn.3051044

Dunford, M., \& Liu, W. (2019). Chinese perspectives on the Belt and Road Initiative. Cambridge Journal of Regions, Economy and Society, 12(1), 145-167. https://oi.org/10.1093/cjres/rsy032

Fuchs, A., \& Rudyak, M. (2019). The motives of China's foreign aid. In Handbook on the International Political Economy of China. Edward Elgar Publishing. https://doi.org/10.4337/9781786435064.00031

Gao, Y., Gao, X., \& Zhang, X. (2017). The 2 C global temperature target and the evolution of the long-term goal of addressing climate change - from the United Nations framework convention on climate change to the Paris agreement. Engineering, 3(2), 272-278. https://doi.org/10.1016/J.ENG.2017.01.022

Goh, E. (Ed.). (2016). Rising China's influence in developing Asia. Oxford University Press. https://doi.org/10.1093/acprof:oso/9780198758518.001.0001

Gong, X. (2020). China's Belt and Road Initiative Financing in Southeast Asia. Southeast Asian Affairs, (1), $77-$ 95. https://doi.org/10.1355/9789814881319-006

Hochstetler, K. A. (2012). The G-77, BASIC, and global climate governance: a new era in multilateral environmental negotiations. Revista Brasileira de Politica Internacional, 55(SPE), 53-69. https://doi.org/10.1590/S0034-73292012000300004

Hopewell, K. (2015). Different paths to power: The rise of Brazil, India and China at the World Trade Organization. Review of international political economy, 22(2), 311-338. https://doi.org/10.1080/09692290.2014.927387

International Monitory Fund (IMF). (2015, May 26). Press Release: IMF Staff completes the 2015 Article IV Consultation Mission to China. Retrieved June 6, 2020, from https:/www.imf.org/en/News/Articles/2015/09/14/01/49/pr15237

Jia, W. (2017). Now, Globalization with Chinese Characteristics. Yale Global Online. Retrieved June 2, 2020 , from http://yaleglobal.yale.edu/content/now-globalization-chinese-characteristics

Jin, X., Li, D. D., \& Wu, S. (2016). How will China shape the world economy?. China Economic Review, 40, 272280. https://doi.org/10.1016/j.chieco.2016.07.006

Kerr, D. (2015). Conclusion: How Close Is China to National Rejuvenation?. In China's Many Dreams (pp. 246261). Palgrave Macmillan, London. https://doi.org/10.1057/9781137478979_11

Khan, M. K., Sandano, I. A., Pratt, C. B., \& Farid, T. (2018). China's belt and road initiative: a global model for an evolving approach to sustainable regional development. Sustainability, 10(11), 4234. https://doi.org/10.3390/su10114234

Kitano, N. (2017). A note on estimating China's foreign aid using new data: 2015 preliminary figures. Tokyo: Japan International Cooperation Agency (JICA) Research Institute.

Kwaśnicki, W. (2011). China, India, and the future of the global economy. Ekonomia, (15), 154-185.

Lai, T. L., Tang, J., \& Yin, H. (2018). Spatial Economics in the Era of One Belt One Road and CounterGlobalization. Modern Economy, 9(1), 61-66. https://doi.org/10.4236/me.2018.91004

Lehmacher, W. (2016, November). Why China could lead the next phase of globalization. In World Economic Forum.

Luft, G. (2016). It takes a road: China's one belt one road initiative: An American response to the new silk road. Institute for the analysis of global security.

Luolin, W. (Ed.). (2015). China's WTO accession reassessed. Routledge. https://doi.org/10.4324/9781315758602 
M\&A Report 2020: China, Carl Li, AllBright Law Offices. Retrieved June 2, 2020, from https://www.iflr.com/article/b1lmx69kvmxdgk/mampa-report-2020-china

Mazarr, M. J., Heath, T. R., \& Cevallos, A. S. (2018). China and the international order. Rand Corporation. https://doi.org/10.7249/RR2423

Medeiros, E. S. (2019). The Changing Fundamentals of US-China Relations. The Washington Quarterly, 42(3), 93-119. https://doi.org/10.1080/0163660X.2019.1666355

Meltzer, J. P., \& Shenai, N. (2019). The US-China economic relationship: A comprehensive approach. https://doi.org/10.2139/ssrn.3357900

Mohan, G., \& Power, M. (2008). New African choices? The politics of Chinese engagement. Review of African Political Economy, 35(115), 23-42. https://doi.org/10.1080/03056240802011394

Mohieldin, M. (2017). Belt and Road Initiative: A Global Effort for Local Impact. Connecting Cities for Inclusive and Sustainable Development. World Bank. Retrieved June 1, 2020, from https://www.worldbank.org/en/news/feature/2017/09/26/bridge-for-cities-speech-by-mahmoud-mohieldin

Ohashi, H. (2015). China's external economic policy in shifting development pattern. Public Policy Review, 11(1), 141-173.

Ohashi, H. (2018). The Belt and Road Initiative (BRI) in the context of China's opening-up policy. Journal of Contemporary East Asia Studies, 7(2), 85-103. https://doi.org/10.1080/24761028.2018.1564615

Ordóñez de Pablos, P. (Ed.). (2016). Managerial strategies and solutions for business success in Asia. IGI Global. https://doi.org/10.4018/978-1-5225-1886-0

Pencea, S. (2017). A look into the complexities of the One Belt, One Road Strategy. Global Economic Observer, $5(1), 142$.

Ra, S., \& Li, Z. (2018). Closing the Financing Gap in Asian Infrastructure. Retrieved June 25, 2020, from https://www.adb.org/sites/default/files/publication/431261/swp-057-financing-gap-asian-infrastructure.pdf

Ravenhill, J. (Ed.). (2017). Global political economy. Oxford University Press. https://doi.org/10.1093/hepl/9780198737469.001.0001

Renminwang. (2018, June 24). Xi Jinping's Important Address at the Central Work Conference on Foreign Affairs. Renminwang.

Rolland, N. (2017). China's "Belt and Road Initiative": Underwhelming or game-changer?. The Washington Quarterly, 40(1), 127-142. https://doi.org/10.1080/0163660X.2017.1302743

Shambaugh, D. L. (2013). China goes global: The partial power (Vol. 409). Oxford: Oxford University Press.

Shimomura, Y., \& Ohashi, H. (Eds.). (2013). A study of China's foreign aid: An Asian perspective. Springer. https://doi.org/10.1057/9781137323774

UNCTAD, U. (2017). World Investment Report 2017: investment and the digital economy. In United Nations Conference on Trade and Development, United Nations, Geneva.

Watanabe, S. (2013). Implementation system: Tools and institutions. In A Study of China's Foreign Aid (pp. 5881). Palgrave Macmillan, London. https://doi.org/10.1057/9781137323774_4

Woetzel, J. (2019). China and the world: Inside the dynamics of a changing relationship.

Xihua. (2015). Vision and Actions on Jointly Building Silk Road Economic Belt and 21st-Century Maritime Silk Road. Xihua. Retrieved June 1, 2020, from https://eng.yidaiyilu.gov.cn/qwyw/qwfb/1084.htm

Zheng, Y. (2020). Rediscovering continentalism: the new geographic foundations of Chinese power. International Politics, 1-35. https://doi.org/10.1057/s41311-019-00206-7

\section{Notes}

Note 1. Based on the actual effective exchange rate ("BIS, effective exchange rate").

Note 2. SWIFT. 2017. "RMB Tracker January 2017.” Available at. https://www.swift. com/file/46706/download?token=MV4-fsu (Accessed on 28 May, 2020).

Note 3. The database included 4373 projects provided by China in different 140 countries during 2000-14, with a total value of US\$354.4 billion. 


\section{Copyrights}

Copyright for this article is retained by the author(s), with first publication rights granted to the journal.

This is an open-access article distributed under the terms and conditions of the Creative Commons Attribution license (http://creativecommons.org/licenses/by/4.0/). 